University of Nebraska - Lincoln

DigitalCommons@University of Nebraska - Lincoln

$9-2010$

\title{
Sugar Beet Fertilization
}

Gary W. Hergert
University of Nebraska-Lincoln, ghergert1@unl.edu

Follow this and additional works at: https://digitalcommons.unl.edu/panhandleresext

Hergert, Gary W., "Sugar Beet Fertilization" (2010). Panhandle Research and Extension Center. 66.

https://digitalcommons.unl.edu/panhandleresext/66

This Article is brought to you for free and open access by the Agricultural Research Division of IANR at DigitalCommons@University of Nebraska - Lincoln. It has been accepted for inclusion in Panhandle Research and Extension Center by an authorized administrator of DigitalCommons@University of Nebraska - Lincoln. 
Published in Sugar Tech: An International Journal of Sugar Crops and Related Industries 12: 3-4 (September and December 2010), pp. 256-266; doi: 10.1007/s12355-010-0037-1

Copyright (C) Society for Sugar Research \& Promotion; published by Springer Verlag. Used by permission.

Submitted September 14, 2010; accepted November 9, 2010; published online February 1, 2011.

\title{
Sugar Beet Fertilization
}

\author{
Gary W. Hergert
}

Panhandle Research and Extension Center, University of Nebraska-Lincoln, 4502 Avenue I, Scottsbluff, NE 69101, USA; email ghergert1@unl.edu

\begin{abstract}
Global sugar beet production spans diverse regions and a wide range of climatic and agroecological regions from rainfed to irrigated production which presents unique management challenges. Sound nutrient management now and into the future must be balanced between production efficiency and managing to have less impact on the environment. $\mathrm{N}$ management continues to improve with more precise $\mathrm{N}$ rates. Soil testing for $\mathrm{N}$ supplying capability plus residual $\mathrm{N}$ will need to be increased to enhance productivity and $\mathrm{N}$ use efficiency. Newer cultivation techniques, $\mathrm{N}$ placement and timing can also fine tune $\mathrm{N}$ rates. In irrigated areas, improvements in $\mathrm{N}$ management will be coupled with better water management and conversion of furrow irrigation to sprinklers will accelerate improvements. Enhanced efficiency fertilizer products hold promise but require additional research under a range of conditions to determine cost and production effectiveness. Management for secondary and micronutrients seems adequate at this time. Precision agricultural applications for expanded site specific management in sugar beet are just beginning. Work with maize and wheat point to the potential of creating different management zones in fields and by using remote or close sensing to determine $\mathrm{N}$ status for $\mathrm{N}$ applications. Similar research will be needed to continue efficient sugar beet production.
\end{abstract}

Keywords: soil testing, site specific, nitrate-N, fertilizer efficiency, plant sensors, environmental effects

\section{Introduction}

Sugar beet has a long and storied past with its 'literal' roots in Europe before being 'transplanted' to North America (Coons et al. 1955; Winner 1993). Today, sugar beet accounts for about 35\% of the world's sugar production (USDA-FAS 2010). Sugar beet production in North America is spread across four diverse regions in the USA (Figure 1) including beets grown in Alberta, Manitoba and Ontario, Canada. European production ranges from the Baltic states to the south in Spain and Greece but it also extends into Morocco. With changes in government policy in Europe because of agreements from recent World Trade Organization negotiations, production has declined in some areas but expanded into eastern Europe and the northern provinces of China. With such a wide range of climatic and agroecological regions from rainfed to irrigated production, there is an equally wide range of soil resources with different nutrient supplying capacity and needs. In an age of precision agriculture, GPS guidance and site specific management, fertilization of sugar beet must be approached from a similar basis.

There are numerous excellent references to fertilizer management and liming for sugar beet production (Cariolle and Duval 2006; Christenson and Draycott 2006; Draycott 1972, 1993). The purpose of this chapter is to review and reference those works and define the current situation of fertilizer management for sugar beet, but to also address future needs and developments to keep sugar beet a profitable crop for growers. In an age of enhanced internet connectivity, Twitter and Face- 


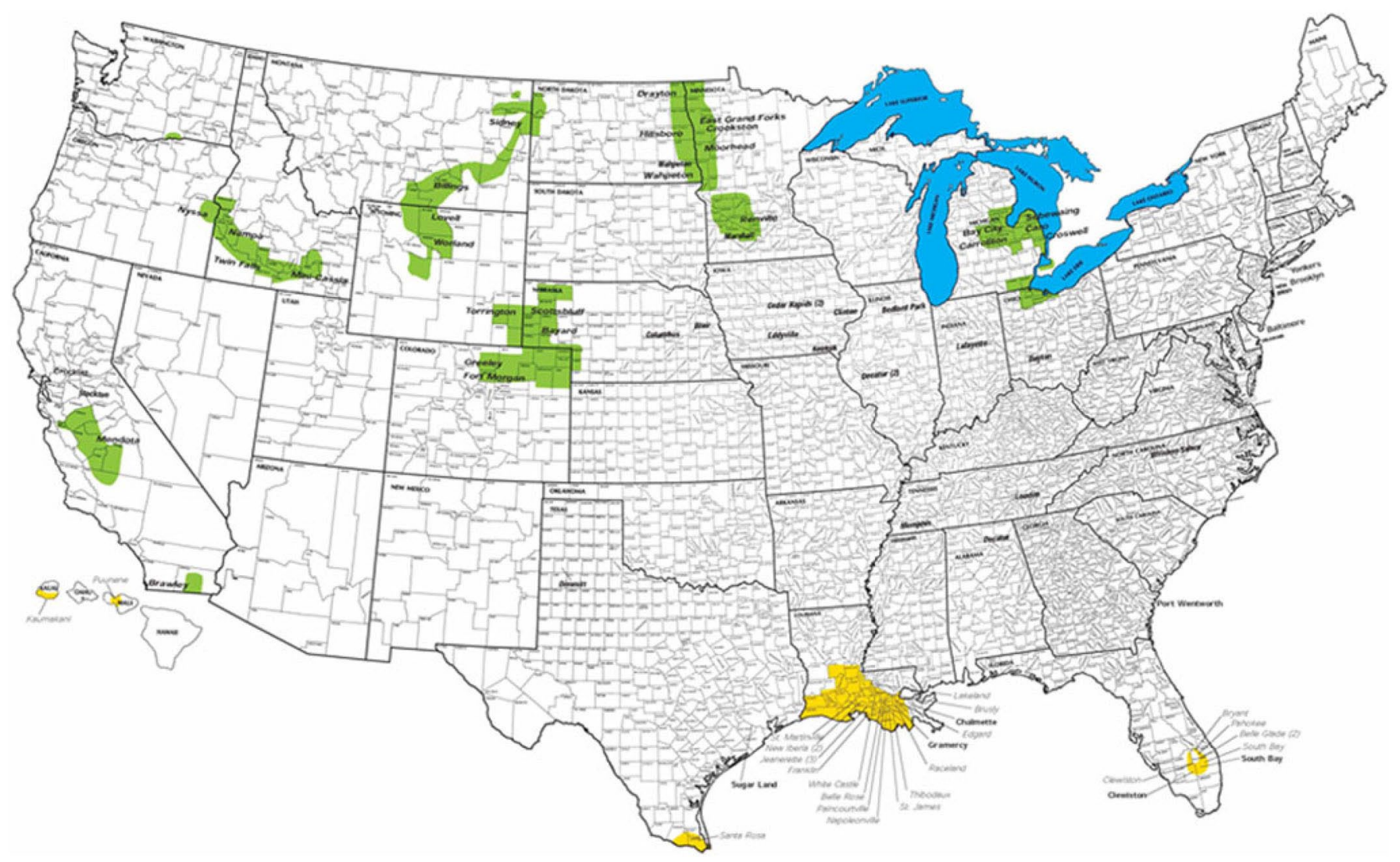

Figure 1. Sugar beet production areas in the United States.

book, we must think about how we will deliver new information to reach the next generation of sugar beet growers.

\section{Present Situation}

Fertilizer management is the science, practice and art of understanding fertilizer source, placement, rate and timing as they relate to fertilizer use efficiency and the economics of production. The interaction of those management factors with different agroecological areas and soils leads to very different recommendations for the different nutrients. It also makes management and fertilizer recommendations truly regional and site specific.

Another constraint for any crop producer today in most countries is meeting the challenges of producing more of the food consumers want and expect without harming the environment This means keeping most of the nutrients in the crop and on the field or farm. Good nutrient management is as much about the fertilizers a producer purchases as it is about managing them to have limited impacts on the environment around and beyond the farm. This chapter will discuss the major nutritional needs of the crop but primarily the fertilizer management required to manage fertilizer rate, timing and placement. It will also discuss future needs and developments for improving management with new tech- niques related to precision agriculture, remote and close sensing and new or different fertilizer products.

\section{Nitrogen}

Sound nitrogen management is essential for optimal sugar production from beets. Nitrogen is probably the most studied nutrient for sugar beet because of it's direct relationship to yield and because it is the nutrient most limiting plant productivity (Loomis and Conor 1992). The application of too little nitrogen will result in reduced root tonnage, however, the application of too much nitrogen will result in reduced sugar concentrations and increased impurities.

With the advent of significant commercial fertilizer productions after World War II, most of Europe and North America readily adopted commercial $\mathrm{N}$ sources in favor or green or animal manures. Ease and uniformity of spreading and reliability of consistent plant response helped the rapid adoption.

Nitrogen management is closely linked with soil water relationships (Black 1968; Burkhart and Stoner 2008; Cariolle and Duval 2006; Coyne 2008; Draycott 1993; Randall and Goss 2008; Raun and Schepers 2008; Ulrich and Hills 1990). If rainfall were perfectly predictable, managing $\mathrm{N}$ would be much easier (de Koeijer et 


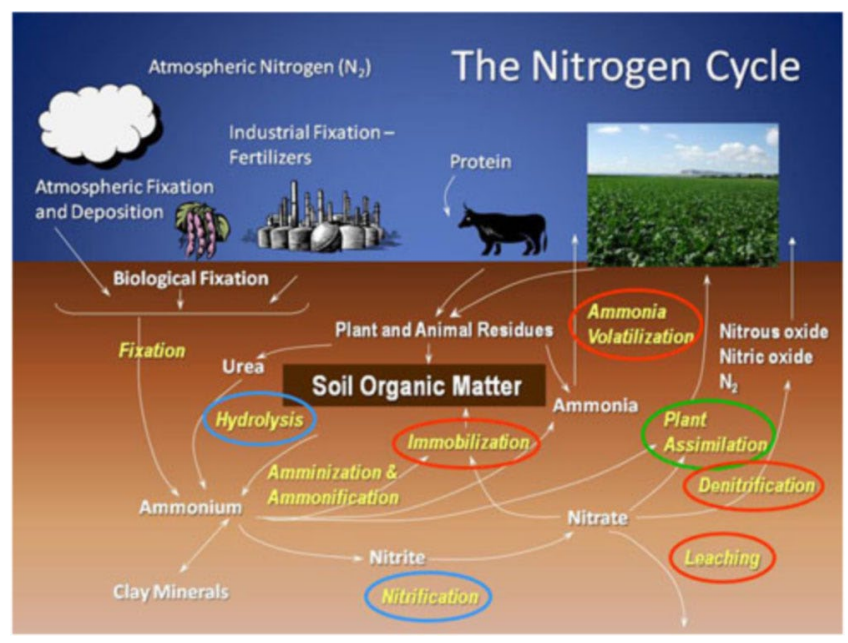

Figure 2. The nitrogen cycle.

al. 2003). Because of the interactions of nitrogen and water, the nitrogen section will be divided into rainfed and irrigated sub-sections to better describe management required by each type of production.

Soil organic matter $(\mathrm{OM})$ is the storehouse of nitrogen regardless of the production regime. Through the process of mineralization and immobilization, $\mathrm{N}$ is cycled from labile and resistant organic forms to mineral forms but also from mineral back to organic forms. We normally think of the process as mostly one way (mineralization) but both processes occur simultaneously (Jansson and Persson 1982; Myrold and Bottomley 2008). Figure 2 shows a stylized N cycle. All forms of $\mathrm{N}$, whether introduced as inorganic or organic sources pass through the cycle and are also subject to loss processes including denitrification and leaching (Coyne 2008; Francis et al., 2008; Mulla and Strock 2008).

When crop or animal residues with a wide C: $\mathrm{N}$ ratio are added to soil, it can affect immobilization and mineralization. C:N ratios below 20:1 usually favor mineralization, whereas higher ratios (25:1 or higher) favor immobilization (Jansson and Persson 1982; Myrold and Bottomley 2008). The timing of the additions of these materials can have little effect or a major effect on crop $\mathrm{N}$ nutrition depending on immobilization and re-mineralization in relation to crop demand for $\mathrm{N}$.

\section{Present Situation-Rainfed Production}

The general shape of $\mathrm{N}$ response of sugar beets for root yield, percent sucrose, sucrose yield and impurities has been understood for years (Gardener and Robertson 1942; Hills and Ulrich 1971) and has been reaffirmed by numerous experiments and covered in recent publications (Cariolle and Duval 2006). The response from a recent experiment using strip-tillage placement shows similar results (Figure 3).
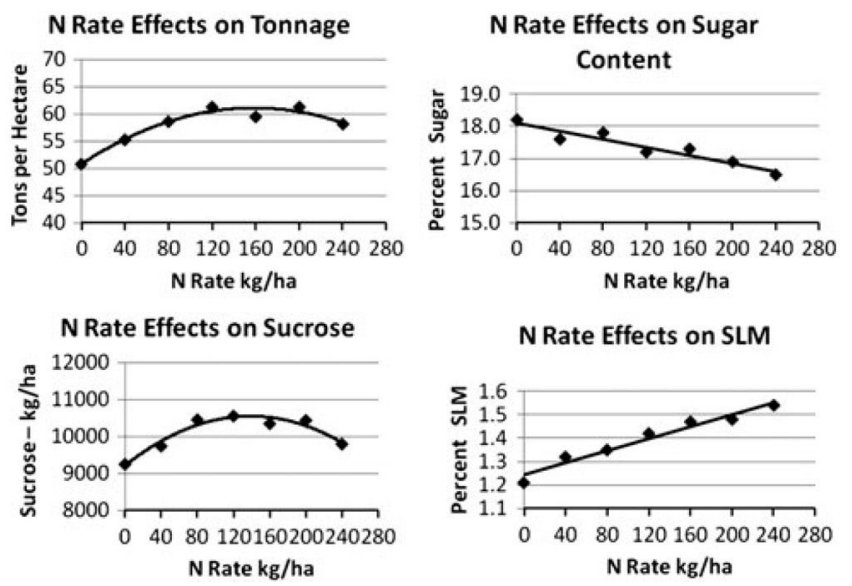

N Rate Effects on SLM

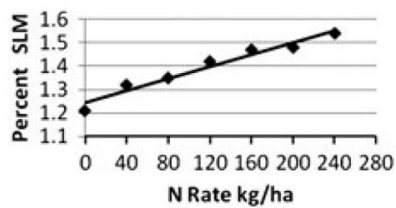

Figure 3. $\mathrm{N}$ rate effects on sugar beet yield parameters. Data from Hergert and Nielsen (2009).

The challenging part of $\mathrm{N}$ management then becomes determining the amount of $\mathrm{N}$ required to produce the most profitable amount of sugar from the field. A quote from Hills and Ulrich (1971) on nitrogen nutrition states "One of the most critical questions a sugar beet grower must answer is how much nitrogen is needed for maximum net return for my beet field?" Unfortunately, this question is also one of the most difficult to answer. The principle is simple enough: the amount of fertilizer $\mathrm{N}$ required is the difference between what the crop requires and what the soil will supply from mineralization and what will be present as usable residual nitrate-N. Determining that with some certainty is still not an exact science for all of the years of study and experimentation, but we are making better approximations.

For good fertilizer $\mathrm{N}$ management, the $\mathrm{N}$ application, $\mathrm{N}$ release and uptake must occur to allow good early canopy growth. This must be maintained to within about 4-6 weeks before harvest without having excess N (Cariolle and Duval 2006; Draycott and Christenson 2003; Hills and Ulrich 1971). As harvest approaches, $\mathrm{N}$ availability should actually decrease to promote enhanced sucrose formation (Ulrich 1955; Loomis and Nevins 1963). Managing that in practice, however, is difficult to achieve.

\section{Predicting and Measuring Soil N Mineralization}

Research on mineralization of $\mathrm{N}$ from soil has been thoroughly reviewed (Cabrera and Kissel 1988; Harmsen and Van Schreven 1955; Dahnke and Johnson 1990; Keeney 1982; Myrold and Bottomley 2008; Stanford 1982) For all of the research into determining $\mathrm{N}$ mineralization by different laboratory methods, no tests are still in use today at remaining US university soil testing laboratories or any of the commercial soil testing labs except for soil OM. A standard part of all soil test- 
ing is the determination of soil organic matter (Dahnke and Johnson 1990). Different university laboratories have developed guidelines based on published research in their state for a given crop that provide annual average estimate of $\mathrm{N}$ release from OM (Dahnke and Johnson 1990). Most often, these averages are used in prediction algorithms which include additional factors (Lamb et al. 2009; Warnake et al. 2009). This is also common in Europe (DEFRA 2010; Draycott and Christenson 2003). The advantage is that organic matter is an easily determined soil property but it is usually only part of the answer.

In Europe, electro-ultrafiltration (EUF) has been a more recent attempt at determining available $\mathrm{N}$ from soils (Draycott and Christensen 2003). It has been widely adopted in Austria, Germany and Ireland. Research in other areas (Denmark, France, United Kingdom) has not been as promising due to large variations in the amount of mineralization from year to year. The technique also has not been adopted in North America.

\section{Other Soil Tests for Rainfed Areas}

Research on the use of residual nitrate- $\mathrm{N}$ tests in the US began in the 1960s (Hergert 1987). Until that time mineral $\mathrm{N}$ tests were considered to be of limited value (Bremner 1965); (Stewart et al. 1975) prepared a generalized average soil-water percolation map for US maize production which related well to potential areas for use based on annual leaching potential. Surveys of soil testing labs (Hergert 1987) showed adoption and current research at that time. The Red River Valley in western Minnesota was already using nitrate tests in the 1980s. Annual rainfall in that area ranges from 480 to $650 \mathrm{~mm} /$ year. Soil nitrate testing has a good probability of success west of the Mississippi River (Bronson 2008; Hergert 1987) or in regions with less than $600 \mathrm{~mm}$ of precipitation. East and north of this region, rainfall increases and evapotranspiration demand is somewhat lower leading to more nitrate leaching. In these areas, nitrate has been shown to help predict $\mathrm{N}$ need but with less certainty than in drier areas (Draycott and Christensen 2003).

\section{N Rate Recommendations for Rainfed Areas}

In rainfed areas, managing $\mathrm{N}$ rate, placement and timing can be a challenge due to the uncertainty of precipitation (de Koeijer et al. 2003). This can have significant effects on $\mathrm{N}$ use recovery and efficiency because of $\mathrm{N}$ losses from leaching or denitrification (Coyne 2008; Mulla and Strock 2008; Francis et al. 2008). Most N recommendations in rainfed areas of North America and Europe are based on soil analyses similar to those described above. These methods are a modified classic mass-balance approach to estimate fertilizer $\mathrm{N}$ need based on crop $\mathrm{N}$ requirements, soil contributions (mineralized $\mathrm{N}$ and residual $\mathrm{N}$ ) and other $\mathrm{N}$ source contributions (previous crop or manure) as modified by $\mathrm{N}$ uptake efficiency (Meisinger et al. 2008; Stanford 1982). This approach has been effectively used in France (Remy and Hebert 1977; Machet et al. 1990) on more than $60 \%$ of the crop. It also includes measuring mineral $\mathrm{N}$ to a $90 \mathrm{~cm}$ depth before planting. A simplified version using mineral $\mathrm{N}$ to a $60 \mathrm{~cm}$ depth is used in Belgium (Cariolle and Duval 2006).

In the United Kingdom, the Department of the Environment, Food and Rural Affairs (DEFRA) has recently published updated information for a number of crops including sugar beet (DEFRA 2010). It uses a field-classification system to access soil nitrogen supply (mineralization term) but also makes provisions for soil sampling to a $90 \mathrm{~cm}$ depth for mineral N. It has an option for no sampling and produces an estimate based on previous crop, fertilizer and manure additions, soil type and winter rainfall. As noted earlier, EUF is used in Germany, Austria and Ireland.

In North American rainfed production areas, there is a mix of $\mathrm{N}$ recommendations based on soil type and yield potential as well as sampling for mineral N (Franzen 2003; Lamb et al. 2009; Warnake et al. 2009). Research reviews between scientists and grower organizations are held each year in many areas and serve as a basis for modifying recommendations and making changes that incorporate new information. As an example, the production guide for the Red River valley ( http://www.sbreb.org/production/production.htm ) includes a date after which recommendations should not be used. With more web-based information, providing real-time access to the most current information is becoming the norm. An example of how recommendations vary is presented in Table 1 which shows recommendation equations for different areas.

$\mathrm{N}$ recommendations systems have evolved and are quite different from region to region based on local research and interpretation. The important factor is that these differences reflect a good degree of site specificity that is important for improved nutrient use efficiency and lower environmental effects.

\section{N Timing and Placement in Rainfed Production}

The numerous experiments defining differences or similarities between $\mathrm{N}$ sources has usually shown little difference (Cariolle and Duval 2006; Draycott and Christenson 2003; Draycott 1972, 1993; Ulrich and Hills 1990). Significant differences, however have been shown for $\mathrm{N}$ timing and placement. A thorough review by van Burg et al. (1983) showed that application of $50-75 \%$ of the $\mathrm{N}$ up to 4-6 weeks after sowing gave similar results compared to seedbed application and that later $\mathrm{N}$ applications increased the risk of reduced sugar content. 
Table 1. N recommendations for sugar beets for different rainfed regions. ${ }^{\text {a }}$

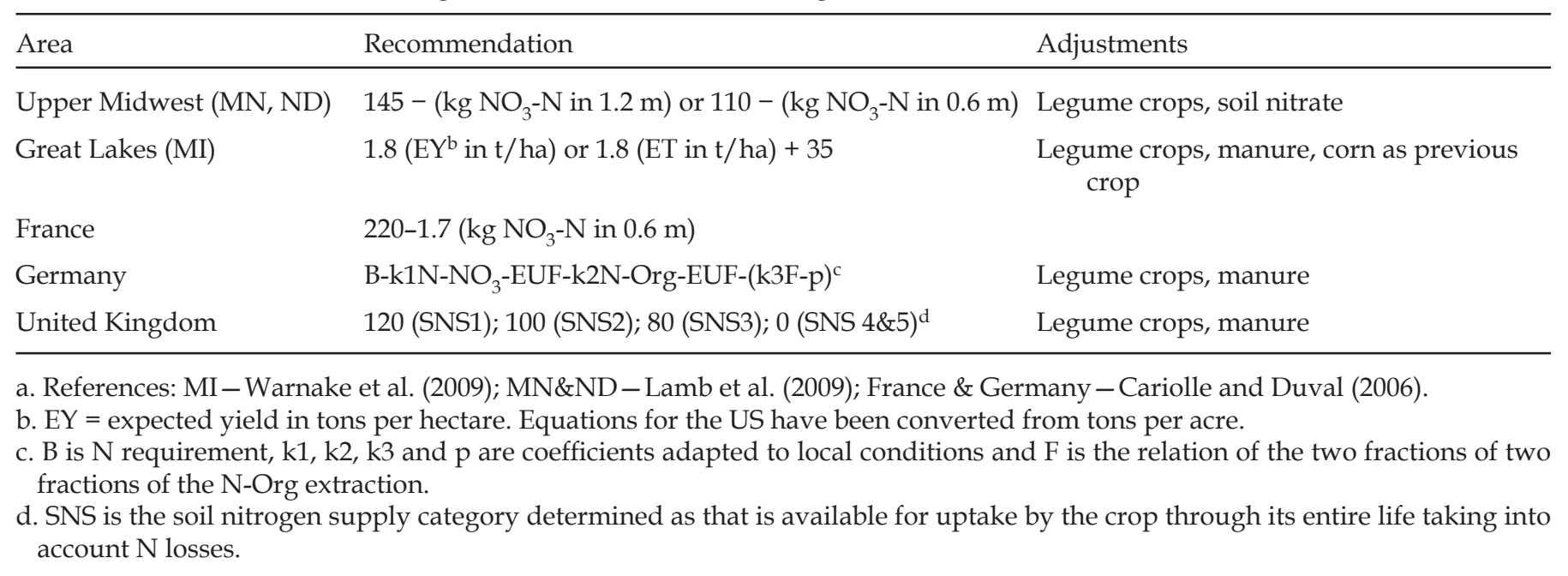

During the last 30 years, the window for $\mathrm{N}$ application in rainfed production areas has generally been reduced to spring time before planting through early in the growing season as a means of improving $\mathrm{N}$ use efficiency and reducing environmental effects, primarily leaching (DEFRA 2010; Draycott and Christenson 2003). Those studies often show that spring application is superior to fall application, primarily due to lower $\mathrm{N}$ loss.

Placement studies may or may not show differences. The primary reason for differences is often positional availability due to leaching (Draycott 1993) or a toxic effect from too much fertilizer close to seedlings (Blumenthal 2001; Last et al. 1983). Foliar feeding also has not shown an advantage (Lamb and Moraghan 1993) to soil-applied N. Recently there has been interest in reduced tillage systems using different application method including banding and point-injection. There have been few reports from rainfed areas (Cavalaris and Gemtos 2002; Overstreet, 2009). Part of the limitation in reduced till systems is weed control which can lower yields (Cavalaris and Gemtos 2002) In the USA, introduction of RoundUp Ready ${ }^{\circledR}$ technology, however, has accelerated reduced tillage adoption. Research from Europe and the US was reported at the 2010 IIRB conference in Copenhagen (http://www.iirb.org/site/ en/215/abstracts-and-proceedings.html ) (Figure 3).

Present Situation-Irrigated Production

Soil Tests and N Rate Recommendations for Irrigated Conditions - In drier climates where irrigation is required, irrigation management is a key to $\mathrm{N}$ management. In the US, sprinkler irrigation continues to grow and in many areas is replacing furrow irrigation (USDA-NASS 2010). The enhanced efficiencies from improved water application and distribution improved uniformity in plant growth and rooting. Currently, the main consideration for $\mathrm{N}$ fertilizer recommendations are based on residual nitrate in the soil (Blumenthal 2001; Davis and Westfall 2009; Jacobsen et al. 2003).

In many irrigated areas, soils were developed under semiarid conditions and soil organic matter levels are low and consequent $\mathrm{N}$ mineralization is also low (Anderson and Peterson 1988; Bilboa et al. 2004; Carter and Traveller 1981; Hills and Ulrich 1971) so it is less of a factor in developing $\mathrm{N}$ recommendations than in rainfed areas with higher OM (Figure 4).

Rooting depths under irrigation often reach depths of at least $1.2 \mathrm{~m}$, but often extend below $1.8 \mathrm{~m}$ (Peterson et al. 1979). A good example is shown in Figure 5. Early research clearly established the importance of this means of improving $\mathrm{N}$ recommendations (Gilbert et al. 1981; James et al. 1971; Reuss and Rao 1971) and other work established sugar beet $\mathrm{N}$ uptake from deeper levels (Anderson et al. 1972).

In irrigated areas of Spain, preplant measurement of soil nitrate has also proven to be very effective in distinguishing between responsive and non-responsive sites (Bilboa et al. 2004). A critical level of $39 \mathrm{mg} \mathrm{kg}^{-1}$ was established that maximized root and sucrose yield. When a price correction was applied for sucrose content (a practice common in Spain and the US), the critical level was $33 \mathrm{mg} \mathrm{kg}^{-1}$.

\section{N Timing and Placement Under Irrigation}

As noted in the section on rainfed production, few differences between different $\mathrm{N}$ timings and placement for $\mathrm{N}$ sources have been shown under irrigated conditions (Carter and Traveller 1981; Draycott and Christenson 2003; Hills and Ulrich 1971). The strongest evidence for the advantage of splitting $\mathrm{N}$ applications is from a detailed study of $\mathrm{N}$ timing conducted by Anderson and 


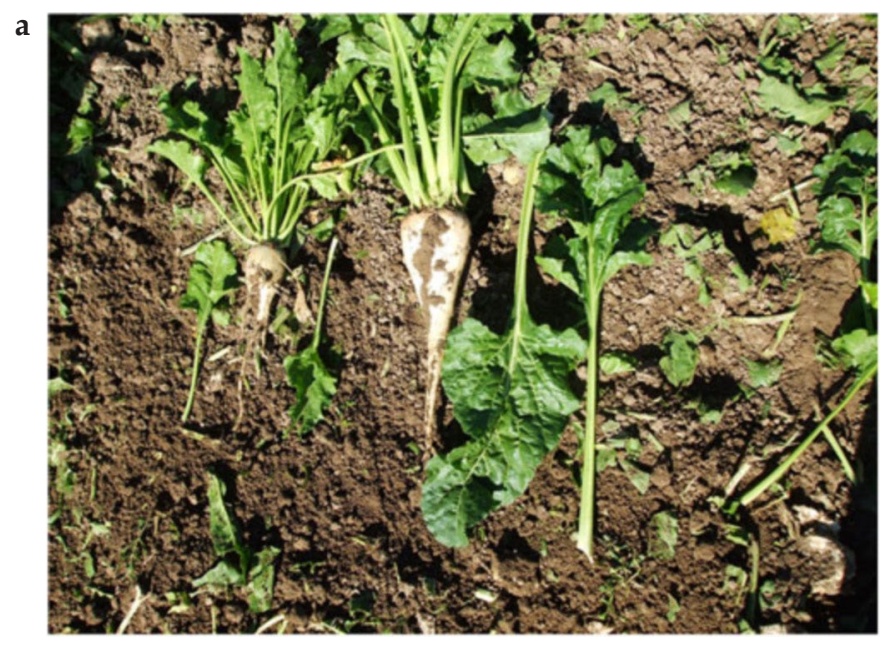

b
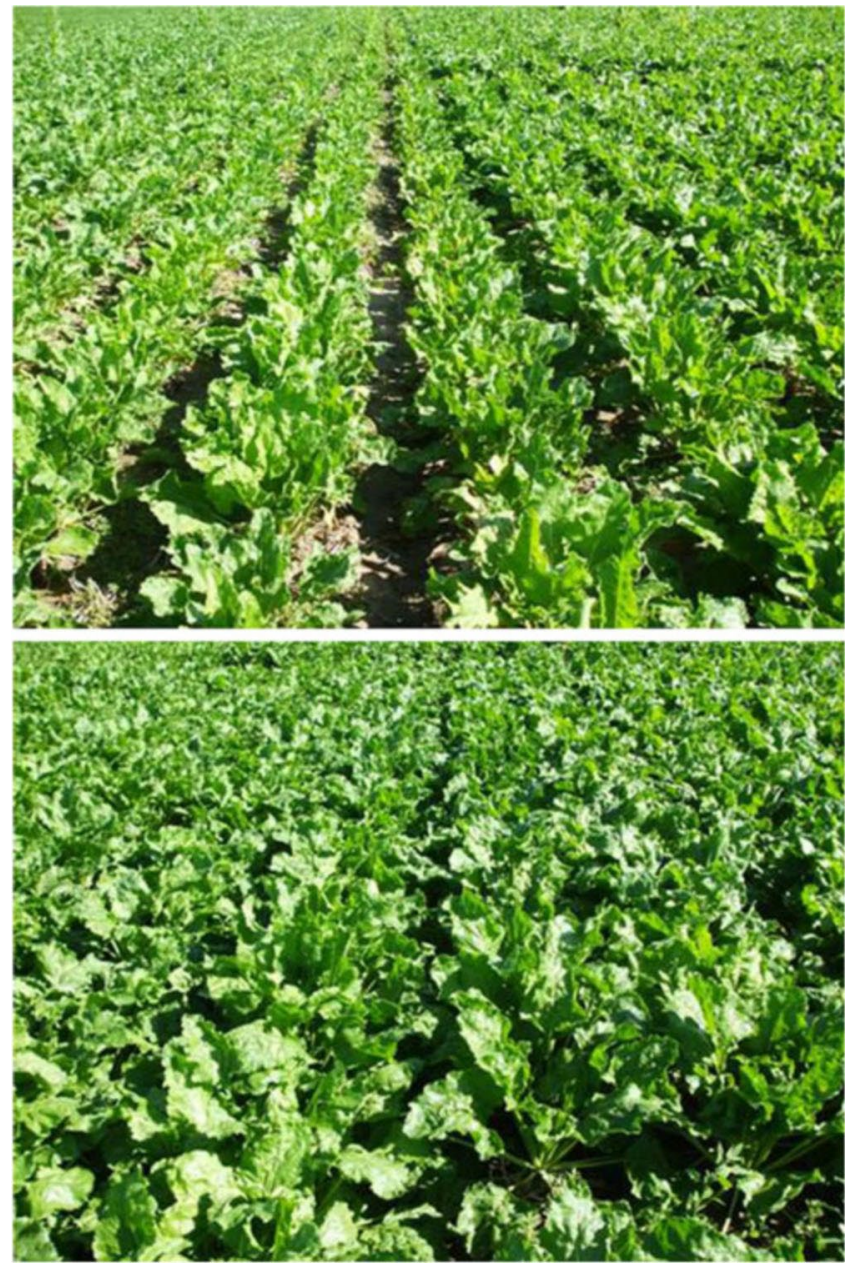

Figure 4. a) N sufficient and deficient sugar beets in early August in western Nebraska, USA. b) Field showing N deficient (top) and N sufficient (bottom) sugar beets in early August in western Nebraska, USA.

Peterson (1988) using $\mathrm{N}$ rates from 30 to $270 \mathrm{~kg}^{-1}$ with weekly splits of 30,60 or $90 \mathrm{~kg} \mathrm{~N}$. The experimental site was depleted of residual nitrate by previous crop-

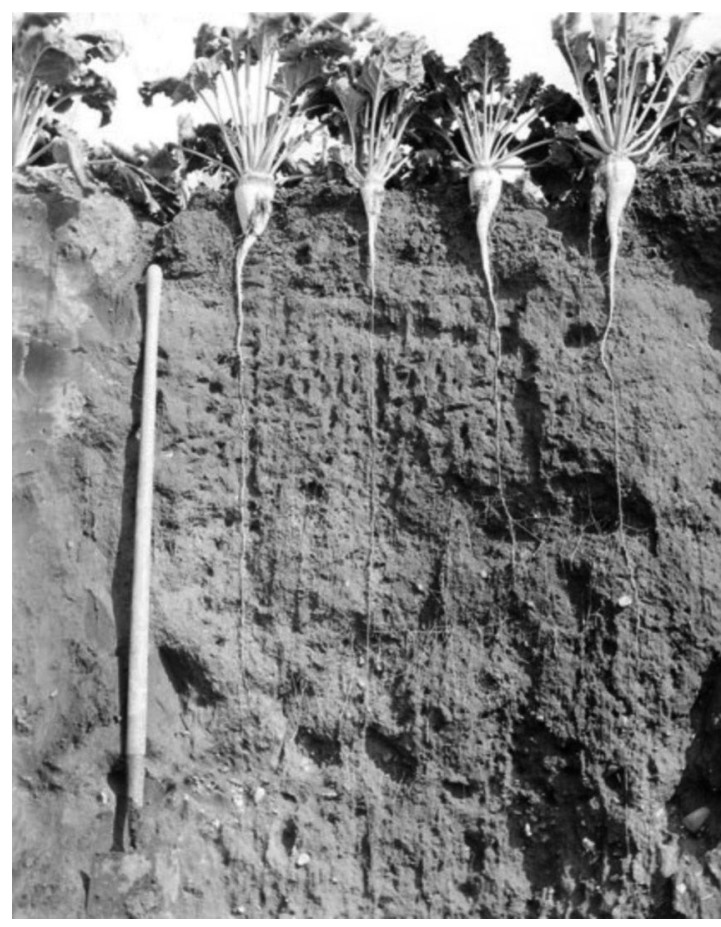

Figure 5. Rooting depth of sugar beet. Photo taken in 1930 by Lyman Andrews, Agricultural Manager for Great Western Sugar Co. at Scottsbluff, NE, USA. An irrigation ditch broke out and cut a deep channel in a sugar beet field exposing the roots. The irrigation shovel on the left is about $1.5 \mathrm{~m}$ in length.

ping and leaching the previous year. In two of three years (without hail), $180 \mathrm{~kg} \mathrm{~N}$ was required for maximum yield with a soil residual of only $40 \mathrm{~kg}$ nitrate in $1.8 \mathrm{~m}$. The six splits of $30 \mathrm{~kg} \mathrm{~N}$ per week produced more sucrose than did three $60-\mathrm{kg}$ portions or two $90-\mathrm{kg}$ portions of N. No similar detailed work has been conducted but this work points to the potential of more precision with multiple timings for the future. This is very practical today with injection of $\mathrm{N}$ solution and center pivot irrigation.

Precision $\mathrm{N}$ placement has been an option for over 20 years but limited work has been done with sugar beet (Baker et al. 1989; Halvorson and Hartman 1988). A recent study compared preplant point injection (PI), knifed banding (KB) and broadcast incorporated (BI) $\mathrm{N}$ (Stevens et al. 2007). The PI injection was $8 \mathrm{~cm}$ from the seed row whereas the KB was $18 \mathrm{~cm}$ from the seed row. The authors concluded that PI enhanced root yield while having the least effect on sucrose content and improved nitrogen use efficiency (NUE). PI generally produced the highest yields and NUE and was similar to $\mathrm{KB}$. Both were an improvement over BI.

Strip tillage (ST), which is also referred to as zone tillage, loosens soil where the seed row will be while leaving the inter-row soil and any crop residue undisturbed. This provides a compromise between conventional tillage (CT) and no-till systems (NT). Early re- 
search in sugar beet with ST was favorable (Halvorson and Hartman 1984) but the power-driven rotary strip tillage implement did not gain commercial production due to slow ground speeds and high maintenance costs.

In the last 10 years many companies have developed machinery that has gained wide acceptance in maize and soybean production in the US Corn Belt (Al-Kaisi and Licht 2004). Most of these equipment configurations consist of a single-shank and a series of coulters and packer wheels. On many of the shanks, fertilizer can be banded within the tilled zone at various depths below the seed row. There have been limited studies with sugar beet due to equipment availability and cost that fits conventional plot work, but recent studies have shown the method to be equal or better than conventional broadcasting of $\mathrm{N}$ (Evans et al. 2010; Hergert and Nielsen 2009; Stevens et al. 2007). The energy requirements are considerably less than with conventional moldboard plowing and subsequent seedbed preparation. The advent of Roundup Ready sugar beet seed in the US has prompted increased use of this method because of improved weed control in reduced tillage situations.

The studies discussed point to the future of precision agriculture and that improvements in $\mathrm{N}$ use efficiency and lower rates are still attainable in the twenty first century.

\section{Phosphorus, Potassium and Other Nutrients}

Phosphorus $(\mathrm{P})$ and potassium $(\mathrm{K})$ are major nutrients needed for sugar beet production. In the early production years, soils were often low in P. Animal manures contain significant $P$, but were usually spread to supply limited amounts of $\mathrm{N}$ and also limited amounts of $\mathrm{P}$. The advent of commercial fertilizer $P$ sources and support of $\mathrm{P}$ fertility by sugar companies led to higher soil $\mathrm{P}$. Today only small increases (if any) in yield from $\mathrm{P}$ occur in areas with a history of production. This may not be the case, however, in newer areas of production. The advantage for these areas is the availability of soil tests for many different soil types or conditions and recommendations that can be adapted from other areas. A similar situation exists for soil K.

Early $\mathrm{P}$ placement studies on low $\mathrm{P}$ soils often showed differences between broadcasting and banding (Schmehl and James 1971). This same review showed banding below the seed was even superior to banding $5 \mathrm{~cm}$ to the side and below the seed. Summaries of more recent work have not always shown a clear advantage (Draycott and Christenson 2003). Soil testing is an important tool in managing $\mathrm{P}$ to maintain adequate levels of $\mathrm{P}$ but is equally important to determine when soil $\mathrm{P}$ levels are reaching levels that may cause environmental problems. This is a major concern in both North Amer- ica and Europe and P levels are maintained to assure good production while reducing soil test levels to not cause excessive $P$ losses primarily through erosion.

Most soils developed under higher rainfall (>500 mm/ year) have lost basic cations during the soil development process. Many of these soils require liming and K. In drier regions of the world where sugar beets are irrigated, soils usually have much higher potassium soil test levels than needed for optimal sugar beet production.

The likelihood of obtaining a response to sulfur fertilizers on sugar beets in irrigated areas is quite small because irrigation water often contains sufficient sulfate to meet $S$ requirements. The problem was noted years ago in California (Ulrich and Hills 1969) but has not been reported as a concern in recent US research (Draycott and Christenson 2003). If sugar beets are grown on soils with less than $1 \%$ organic matter and irrigation water levels of sulfate are less than $6 \mathrm{mg} / \mathrm{kg}, 10 \mathrm{~kg} / \mathrm{ha} S$ may be applied. In higher rainfall areas of the USA, there have not been significant increases from $S$ application (Draycott and Christenson 2003). Because of environmental concerns, commercial fertilizers (primarily phosphates) now have much lower levels of $S$ as trace contaminants. Cleanup of stack gasses from different industries across the USA and Europe has also reduced atmospheric deposition (wet and dry fall) so the potential exists for $S$ needs in the future.

In the USA, the DTPA soil test (Lindsay and Norvell 1978) has been calibrated to determine critical levels of $\mathrm{Zn}, \mathrm{Fe}, \mathrm{Mn}$ and $\mathrm{Cu}$. Fertilizer recommendations have been developed for maize, but there has been little work and response for any micronutrients in sugar beet. As a safeguard, if the DTPA zinc soil test level is less than $0.5 \mathrm{mg} / \mathrm{kg}$, growers in the western US are advised to apply $1 \mathrm{~kg} \mathrm{Zn/ha} \mathrm{in} \mathrm{a} \mathrm{band} \mathrm{or} 5 \mathrm{~kg} \mathrm{Zn} /$ acre broadcast from zinc sulfate or other soluble forms (Blumenthal 2001; Davis and Westfall 2009). The likelihood of obtaining a response in sugar beets to the application of other fertilizer nutrients has generally not been reported (Draycott and Christenson 2003; Viets and Robertson 1971).

\section{Future Needs and Developments}

Future needs in sugar beet fertilization will center around enhanced efficiency that supports reduced offfarm effect of nutrients on water resources-both surface and ground water. The nutrients of primary interest will be $\mathrm{N}$ and $\mathrm{P}$. Slow release $\mathrm{N}$ products have been available for over 25 years (Hauck 1985) but only a few came into large scale commercial use. Enhanced efficiency fertilizers (EEF) is a newer term for new formulations that control fertilizer release or alter reactions that lead to nutrient losses. The mechanisms or products include fertilizer additives, physical barriers or different 
Table 2. Enhanced efficiency fertilizers currently available in the United States

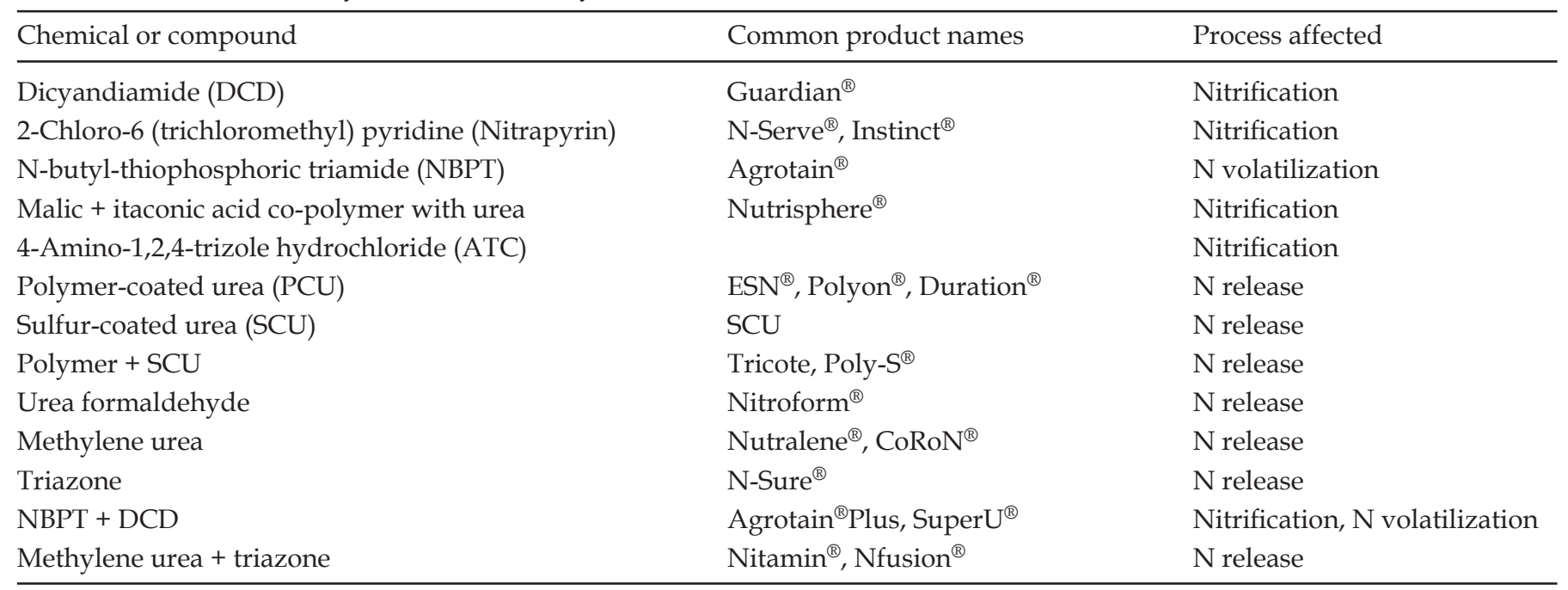

Mention or omission of a commercial company or trade name does not imply endorsement or censure by the author or University of Nebraska-Lincoln.

chemical formulations and are similar to earlier versions (Hauck 1985). Most of the product development has been for $\mathrm{N}$ compounds (Table 2).

Most of these products are considerably higher in cost than conventional fertilizers and although some are being actively marketed, many are still in the research phase. It remains to be seen whether any of the products can match the $\mathrm{N}$ uptake demand for the different crops grown, including sugar beets, that will provide major improvements over conventional sources, timing or placement combinations. The enhanced efficiencies must be coupled with accurate rate recommendations to attain improvement. Again, if soil and climatic conditions are not conducive to $\mathrm{N}$ loss, EEFs will be no better than standard fertilizers. They may simply be needed as insurance of yield potential and reduction of losses as opposed to a guarantee of increased yield. They do present some excitement in the mature technology of fertilizers, however.

Site specific management (SSM) or Precision Agriculture (PA) applications continue to advance with GPS guided equipment and mapping for grain crops. About 15 years ago there were predictions of major adoptions of SSM and PA applications including variable rate fertilizer (VRT) application (Hergert 1998). There has been limited adoption of grid sampling and VRT during that time but there has been major adoption of GPS guidance systems. Mapping yield (tonnage) can be accomplished for beets but the challenge with sugar beet is also determining sugar content on-the-go on a spatial basis (Kaffka et al. 2005). The other aspect of PA is managing spatial and temporal variability. Intensive sampling and mapping envisioned 15 years ago (Wollenhaupt et al. 1997) has not occurred on a broad scale. There is still considerable research that needs to be done to improve fertilizer recommendations from whole-field management for SSM (Hergert et al. 1997). A simplification of SSM was the development of the Management Zone concept. Research has shown that is difficult to develop management zones without significant data collection (Schepers et al. 2004).

The growth of sensor technology, however, holds the promise of taking numerous measurements to develop more data-dense maps (Adamchuk et al. 2004). To date, the main parameter of interest measured is soil $\mathrm{pH}$. Electrical conductivity is usually measured (Adamchuk et al. 2004), but it is not a stand-alone parameter that can be directly related to soil nutrient needs. Other sensors are in the development phase and hold promise, but extensive research will need to be done to develop techniques for data management and interpretation that can be translated into usable management recommendations and application maps that can be downloaded into computers that drive application equipment.

Remote or close sensing collects data acquired by a device not in contact with the crop. It could be images from a satellite [e.g. Landsat (USA), Galileo (Europe), GLONASS (Russia), CNSS (China)], aerial photography (digital, regular spectra, hyperspectral, infrared) or it could be close-sensing from sensors placed above the field on a tractor-mounted system or on a center pivot irrigation system. There has been considerable research in the USA during the last 10 years on different methods, primarily crop sensing of maize and wheat for $\mathrm{N}$ management (Raun et al. 2002; Raun et al. 2005; Roberts et al. 2009; Samborski et al. 2009; Solari et al. 2008). In Europe, Yara has provided leadership with the N Sensor system ( http://www.sensoroffice.com/hp_home2/ index.jsp ) in small grains. 
Limited research has been done with sugar beet (Franzen 2004). The challenge is that significant N deficiency may not be detected until a late enough stage of development such that $\mathrm{N}$ additions might affect sugar content. After 10 years of research, the first algorithms for grain crops are just being developed. Research on sugar beets is only beginning, so it will be several years to see if the technology has application.

In irrigated areas, many of the improvements in $\mathrm{N}$ management will be coupled with better water management. Early research (Anderson and Peterson 1988) showed the potential of multiple $\mathrm{N}$ applications. The difficulty with improved management in an era of continuing increased farm size, is the demand of time to perform additional operations.

Past research shows there are significant gains possible from different placement and timing applications. New enhanced efficiency fertilizers also hold promise but are still in early stages of adoption. Crop sensor and soil sensor technology is just being adopted for some crops but not yet for sugar beets. More intensive management can improve efficiency and reduce environmental effects, but the cost or perceived cost in terms of value to the producer must be low enough or provide enough incentive to adopt it or the penalty for not doing it is sufficient to provide the impetus for adoption. As farm operations continue to grow, producers will adopt new technology if it is simple, easy to learn and use, affordable and reduces labor or improves convenience. A good example is the rapid adoption of GPS guidance on tractors and combines in the USA in the last 10 years. The challenge is combining new technologies of products and management that provide growers improved efficiency, simplicity and value. The technologies and products are here, but the improvements that can be made, the cost or perceived cost, changes in government regulations and the value to producers will be determined over the next few years.

\section{References}

Adamchuk, V.I., J.W. Hummel, M.T. Morgan, and S.K. Upadhyaya. 2004. On-the-go soil sensors for precision agriculture. Computers and Electronics in Agriculture 44: 71-91.

Al-Kaisi, M., and M.A. Licht. 2004. Effect of strip tillage on corn nitrogen uptake and residual soil nitrate accumulation compared with no tillage and chisel plow. Agronomy Journal 96: 1164-1171.

Anderson, F.N., and G.A. Peterson. 1988. Effect of incrementing nitrogen application on sucrose yield of sugarbeet. Agronomy Journal 80: 709-712.

Anderson, F.N., G.A. Peterson, and R.A. Olson. 1972. Uptake patterns of ${ }^{15} \mathrm{~N}$ tagged nitrate by sugarbeets as related to soil nitrate level and time. American Society of Sugar Beet Technologists 17: 42-48.
Baker, J.L., T.S. Colvin, S.J. Marley, and M. Dawelbeit. 1989. A point-injector applicator to improve fertilizer management. Applied Engineering in Agriculture 5: 334-338.

Bilboa, M., J.J. Martinez, and A. Delgado. 2004. Evaluation of soil nitrate as a predictor of nitrogen requirement for sugar beet grown in a Mediterranean climate. Agronomy Journal 96: $18-25$.

Black, C.A. 1968. Nitrogen. In Soil-plant relationships, ed. C.A. Black, 405-557. New York, NY: Wiley.

Blumenthal, J.M. 2001. Fertilizing Sugarbeet. In Sugarbeet production guide, ed. R.G. Wilson, 75-80. University of NE. EC01-156.

Bremner, J.M. 1965. Inorganic form of nitrogen. In Methods of soil analysis, Part 2, ed. C.A. Black, et al., 1179-1237. Agronomy monograph no. 9.

Bronson, K.F. 2008. Forms of inorganic nitrogen in soil. In Nitrogen in agricultural systems, ed. J.S. Schepers and W.R. Raun, 31-56. American Society of Agronomy monograph no. 49. Madison, WI, USA: American Society of Agronomy.

Burkhart, M.R., and J.D. Stoner. 2008. Nitrogen in groundwater associated with agricultural systems. In Nitrogen in the environment: Sources, problems, and management, 2nd ed, ed. J.L. Hatfield and R.F. Follet, 177-202. Oxford, UK: Elsevier.

Cabrera, M.L., and D.E. Kissel. 1988. Evaluation of method to predict nitrogen mineralized from soil organic matter under field conditions. Soil Science Society of America Journal 52: 1027-1031.

Cariolle, M., and R. Duval. 2006. Nutrition - nitrogen. In Sugar beet, ed. A.P. Draycott, 169-184. Oxford, UK: Blackwell Publishing Ltd.

Carter, J.N., and D.J. Traveller. 1981. Effect of time and amount of nitrogen uptake on sugarbeet growth and yield. Agronomy Journal 73: 665-671.

Cavalaris, C.K., and T.A. Gemtos 2002. Evaluation of four conservation tillage methods in the sugar beet crop. CIGR ejournal IV; http://0-hdl.handle.net.library.unl. edu/1813/10286

Christenson, D.R., and A.P. Draycott. 2006. Nutrition-phosphorus, sulphur, potassium, sodium, calcium, magnesium and micronutrients - liming and nutrient deficiencies. In Sugar beet, ed. A.P. Draycott, 185-220. Oxford, UK: Blackwell Publishing Ltd.

Coons, G.W., F.V. Owen, and D. Stewart 1955. Improvement of the sugarbeet in the United States. Advances in Agronomy. New York, NY: Academic Press.

Coyne, M.S. 2008. Biological denitrification. In Nitrogen in agricultural systems, ed. J.S. Schepers and W.R. Raun, 201254. American Society of Agronomy monograph no. 49. Madison, WI, USA: American Society of Agronomy.

Dahnke, W.C., and G.V. Johnson. 1990. Testing soils for available nitrogen. In Soil testing and plant analysis. SSSA book series \#3, ed. R.L. Westermann, 127-140. Madison, WI: SSSA.

Davis, J.G., and D.G. Westfall 2009. Fertilizer sugar beets. CSU fact sheet 0.542 .

de Koeijer, T.J., A.J. de Buck, G.A.A. Wossink, J. Oenema, J.A. Renkema, and P.C. Struik. 2003. Annual variation in weather: its implications for sustainability in the case of op- 
timizing nitrogen input in sugar beet. European Journal of Agronomy 19: 251-264.

Department for Environment Food and Rural Affairs. 2010. Fertiliser manual. RB209-8th edition; http://www.defra. gov.uk/rb209-rev-100609.pdf

Draycott, A.P. 1972. Sugar beet nutrition. London, UK: Applied Science Publishers Ltd.

Draycott, A.P. 1993. Nutrition. In The sugar beet crop-science into practice, ed. D.A. Cooke and R.K. Scott, 239-279. London, UK: Chapman and Hall; London, UK: Applied Science Publishers Ltd.

Draycott, A.P. and D.R. Christenson, 2003. Nutrients for sugar beet production: Soil-plant relationships, 7-32, 123-138, 180-181. Wallingford, UK: CABI Publishing.

Evans, R.G., W.B. Stevens, and W.M. Iversen. 2010. Development of strip tillage on sprinkler irrigated sugarbeet. Applied Engineering in Agriculture 26: 59-69.

Francis, D.D., M.F. Vigil, and A.R. Mosier. 2008. Gaseous losses of nitrogen other than through denitrification. In Nitrogen in agricultural systems, ed. J.S. Schepers and W.R. Raun, 255-280. American Society of Agronomy monograph no. 49. Madison, WI, USA: American Society of Agronomy.

Franzen, D.W. 2003. Fertilizing sugarbeet. University of North Dakota bulletin SF-714.

Franzen, D.W. 2004. Delineating nitrogen management zones in a sugarbeet rotation using remote sensing-a review. Journal of Sugar Beet Research 41: 47-60.

Gardener, R., and D.W. Robertson. 1942. The nitrogen requirement of sugar beets. Colorado Agricultural Experiment Station technical bulletin 28, Fort Collins, CO.

Gilbert, A.E., A.E. Ludwick, and D.G. Westfall. 1981. Predicting in season requirements of sugarbeets based on soil and petiole nitrate. Agronomy Journal 73: 1018-1022.

Halvorson, A.D., and G.P. Hartman. 1984. Reduced seedbed tillage effects on irrigated sugarbeet yield and quality. Agronomy Journal 76: 603-606.

Halvorson, A.D., and G.P. Hartman. 1988. Nitrogen needs of sugarbeet produced with reduced-tillage systems. Agronomy Journal 80: 719-722.

Harmsen, G.W., and D.A. Van Schreven. 1955. Mineralization of organic nitrogen in soil. Advances in Agronomy 7: 299-398.

Hauck, R.D. 1985. Slow-release and bioinhibitor-amended nitrogen fertilizers. In Fertilizer technology and use, ed. O.P. Englestad, 293-322. Madison, WI: SSSA.

Hergert, G.W. 1987. Status of residual nitrate-nitrogen tests in the United States of America. In Soil testing: Sampling, correlation, calibration and interpretation, ed. J.R. Brown, 7388. SSSAJ special publication no. \#21. Madison, WI: SSSA.

Hergert, G.W. 1998. A futuristic view of soil and plant analysis and nutrient recommendations. Communications in Soil Science and Plant Analysis 29: 1441-1454.

Hergert, G.W., and R.A. Nielsen 2009. Comparison of strip tillage versus broadcast $\mathrm{N}$ application. Proceedings of the American Society of Sugar Beet Technologists, 35th biennial meeting, Feb 2009.

Hergert, G.W., W.L. Pan, D.R. Huggins, J.H. Grove, and T.R. Peck. 1997. Adequacy of current fertilizer recommendations for site specific management. In The state of site-spe- cific management for agriculture, ed. F.J. Pierce and E.J. Sadler, 283-300. Madison, WI: ASA.

Hills, F.J., and A. Ulrich. 1971. Nitrogen nutrition. In Advances in sugarbeet production: Principles and PRACTICES, ed. R.T. Johnson, et al., 111-136. Ames, IA: Iowa State University Press.

Jacobsen, J., G. Jackson, and C. Jones. 2003. Fertilizer guidelines for montana crops. MSU EB161.

James, D.W., A.W. Richards, W.H. Weaver, and R.L. Reeder. 1971. Residual soil nitrate measurement as a basis for managing nitrogen fertilizer practices for sugar beets. American Society of Sugar Beet Technologists 16: 313-322.

Jansson, S.L., and J. Persson. 1982. Mineralization and immobilization of soil nitrogen. In Nitrogen in agricultural soils, ed. F.J. Stevenson, 229-252. American Society of Agronomy monograph \#22. Madison, WI, USA: American Society of Agronomy.

Kaffka, S.R., S.M. Lesch, K.M. Bali, and D.L. Corwin. 2005. Site-specific management in salt-affected sugar beet fields using electromagnetic induction. Computers and electronics in Agriculture 46: 329-350.

Keeney, D.R. 1982. Nitrogen-availability indices. In Methods of soil analysis. Part 2, ed. A.L. Page, et al., 711-733, 2nd ed. Agronomy monograph no. 9. Madison, WI: ASA and SSA.

Lamb, J.A., A.L. Sims, L.J. Smith, and G.W. Rehm. 2009. Fertilizing sugar beet in Minnesota and North Dakota. University of MN Extension WW-07715.

Lamb, J.A., and J.T. Moraghan. 1993. Comparison of foliar and preplant applied nitrogen fertilizer for sugar beet. Agronomy Journal 85: 290-295.

Last, P.J., A.P. Draycott, A.B. Messem, and D.J. Webb. 1983. Effects of nitrogen fertilizer and irrigation on sugar beet at Broom's Barn 1973-1978. Journal of Agricultural Science (Cambridge) 101: 185-205.

Lindsay, W.L., and W.A. Norvell. 1978. Development of a DTPA soil test for zinc, iron, manganese and copper. Soil Science Society of America Journal 42: 421-428.

Loomis, R.S., and D.J. Conor. 1992. Nitrogen processes. In Crop ecology: Productivity and management in agricultural systems, ed. R.S. Loomis and D.J. Conor, 195-223. Cambridge, UK: Cambridge University Press.

Loomis, R.S., and D.J. Nevins. 1963. Interrupted nitrogen nutrition effects on growth, sucrose accumulation and foliar development of the sugar beet plant. Journal of the American Society of Sugar Beet Technologists 12: 309-322.

Machet, J.M., P. Dubrulle, and P. Louis. 1990. AZOBIL: a computer program for fertilizer $\mathrm{N}$ recommendations based on predictive balance sheet method. Proceedings of the 1st congress of European Society of Agronomy.

Meisinger, J.J., J.S. Schepers, and W.R. Raun. 2008. Crop nitrogen requirements and fertilization. In Nitrogen in agricultural systems, ed. J.S. Schepers and W.R. Raun, 563-612. American Society of Agronomy monograph no. 49. Madison, WI, USA: American Society of Agronomy.

Mulla, D.J., and J.S. Strock. 2008. Nitrogen transport processes in soil. In Nitrogen in agricultural systems, ed. J.S. Schepers and W.R. Raun, 361-400. American Society of Agronomy monograph no. 49. Madison, WI, USA: American Society of Agronomy. 
Myrold, D.D. and P.J. Bottomley. 2008. Nitrogen mineralization and immobilization. In Nitrogen in agricultural systems, ed. J.S. Schepers and W.R. Raun, 157-172. American Society of Agronomy monograph no. 49. Madison, WI, USA: American Society of Agronomy.

Overstreet, L.F. 2009. Strip tillage for sugarbeet production. International Sugar Journal 111: 292-304.

Peterson, G.A., F.N. Anderson, G.E. Varvel, and R.A. Olson. 1979. Uptake of $15 \mathrm{~N}$-labeled nitrate by sugar beets from depths greater than $180 \mathrm{~cm}$. Agronomy Journal 71: 371-372.

Randall, G.W., and M.J. Goss. 2008. Nitrate losses to surface water through subsurface, tile drainage. In Nitrogen in the environment: Sources, problems, and management, 2nd ed, ed. J.L. Hatfield and R.F. Follet, 145-176. Oxford, UK: Elsevier.

Raun, W.R., and J.S. Schepers. 2008. Nitrogen management for improved use efficiency. In Nitrogen in agricultural systems, ed. J.S. Schepers and W.R. Raun, 675-695. American Society of Agronomy monograph no. 49. Madison, WI, USA: American Society of Agronomy.

Raun, W.R., J.B. Solie, G.V. Johnson, M.L. Stone, R.W. Mullen, K.W. Freeman, W.E. Thomason, and E.V. Lukina. 2002. Improving nitrogen use efficiency in cereal grain production with optical sensing and variable rate application. Agronomy Journal 94: 815-820.

Raun, W.R., J.B. Solie, M.L. Stone, D.L. Zavodny, K.L. Martin, and K.W. Freeman. 2005. Automated calibration stamp technology for improved in-season nitrogen fertilization. Agronomy Journal 97: 338-342.

Remy, J.D., and J. Hebert. 1977. Le devenie des engrais azotes dans le sol. Comptes Rendus de l'Acadamie d'Agriculture de France 11: 700-714.

Reuss, J.O., and P.S.C. Rao. 1971. Soil nitrate nitrogen levels as an index of nitrogen fertilizer needs of sugarbeets. American Society of Sugar Beet Technologists 16: 461-470.

Roberts, D.F., V.I. Adamchuk, J.F. Shanahan, R.B. Ferguson, and J.S. Schepers. 2009. Optimization of crop canopy sensor placement for measuring nitrogen status in corn. Agronomy Journal 101: 140-149.

Samborski, S.M., N. Tremblay, and E. Fallon. 2009. Strategies to make use of plant sensors-based diagnostic information for nitrogen recommendations. Agronomy Journal 101: 800-816.

Schepers, A.R., J.F. Shanahan, M.A. Liebig, J.S. Schepers, S.H. Johnson, and A. Luchiari. 2004. Appropriateness of management zones for characterizing spatial variability of soil properties and irrigated corn yields across years. Agronomy Journal 96: 195-202.

Schmehl, W.R., and D.W. James. 1971. Phosphorus and potassium nutrition. In Advances in sugarbeet production: Principles and practices, ed. R.T. Johnson, et al., 137-170. Ames, IA: Iowa State University Press.
Solari, F., R. Ferguson, J. Schepers, and A. Gitelson. 2008. Active sensor reflectance measurements of corn nitrogen status and yield potential. Agronomy Journal 100: 571-579.

Stanford. G. 1982. Assessment of soil nitrogen availability. In Methods of soil analysis. Part 2, ed. A.L. Page, et al., 651688, 2nd ed. Agronomy monograph no. 9. Madison, WI: ASA and SSA.

Stevens, W.B., A.D. Blaylock, J.M. Krall, B.G. Hopkins, and J.W. Ellsworth. 2007. Sugarbeet yield and nitrogen use efficiency with preplant broadcast, banded, or point-injected nitrogen application. Agronomy Journal 99: 1252-1259.

Stewart, B.A., D.A. Woolhiser, W.H. Wischmeier, J.H. Cara, and J.H. Freere. 1975. Control of water pollution from cropland (Vol I.). USDA report. ARS-H-5-1. Washington, DC: US GPO.

Ulrich, A. 1955. Influence of night temperature and nitrogen nutrition on the growth, sucrose accumulation and leaf minerals of sugarbeet plants. Plant Physiology 30: 250-257.

Ulrich, A., and F.J. Hills. 1969. Sugarbeet nutrient deficiency symptoms - a color atlas and chemical guide. Berkeley: University of California, Division of Agricultural Sciences.

Ulrich, A., and F.J. Hills. 1990. Plant analysis as an aid in fertilizing sugarbeet. In Soil testing and plant analysis. SSSA book series \#3, ed. R.L. Westermann, 429-447. Madison, WI: SSSA.

USDA-FAS. 2010. Sugar: World production supply and distribution; accessed July 28, 2010; http://www.fas.usda.gov/ htp/sugar/2010/sugarMay2010.pdf

USDA-National Agricultural Statistics Service. 2010. 2007 Census of agriculture 2008 farm and ranch irrigation survey. http://www.agcensus.usda.gov/Publications/2007/ Online_Highlights/Farm_and_Ranch_Irrigation_Survey/ fris08_1_04.pdf

van Burg, P.F.J., M.R.J. Holmes, and K. Dilz. 1983. Nitrogen supply from fertilizers and manure: Its effect on yield and quality of sugar beet. In Nitrogen and sugar-beet, 189-292. Brussels, Belgium: IIRB.

Viets, F.G., and L.S. Robertson. 1971. Secondary nutrients and micronutrients. In Advances in sugarbeet production: Principles and practices, ed. R.T. Johnson, et al., 171-188. Ames, IA: Iowa State University Press.

Warnake, D., J. Dahl, and L. Jacobs. 2009. Nutrient recommendations for field crops in Michigan. MSU Ext bulletin E2904: 36.

Winner, C. 1993. History of the crop. In The sugar beet crop, ed. D.A. Cooke, and R.K. Scott, 6-7. London: Chapman \& Hall.

Wollenhaupt, N.C., D.J. Mulla, and C.A. Gotway-Crawford. 1997. Soil sampling and interpolation techniques for mapping spatial variability of soil properties. In The state of site-specific management for agriculture, ed. F.J. Pierce and E.J. Sadler, 19-54. Madison, WI: ASA. 